\title{
Nationalism of Border Society: Case Study of Sangir People, Sangihe Regency
}

\author{
Cahyo Pamungkas $1 \bowtie$ \\ ${ }^{1}$ Regional Resources Research Centre, Indonesia Institute of Science
}

DOI: http://dx.doi.org/10.15294/komunitas.v8i1.3669

Received : 5 Juny 2015; Accepted: 22 March 2016; Published: 31 March 2016

\begin{abstract}
This study aims to describe how the maintenance of nationalism has been conducted by the state toward border communities and how far citizens understand the concept of the Homeland and border, national pride, and apprehending the meaning of nationalism. The main source of data used in this study was the result of interviews, focus group discussions, participant observation, and literature studies conducted in Tahu, and Marore (Sangihe). The findings in this study are as follows. First, the acquisition of knowledge about the Homeland as a political concept, as well as national pride border communities today is increasing due to the development of information technology and the maintenance of nationalism efforts undertaken by the Government. Second, nationalism is defined by the state as measured by people's understanding toward the concept of nationalism which is less relevant to the socio-economic context of low income border communities. Third, the maintenance of nationalism efforts can be done to accommodate and provide space for cultural identity development of border communities in Indonesia.
\end{abstract}

Keywords: borders; nationalism; maintenance of nationalism; meaning of nationalism

\section{INTRODUCTION}

Apprehending nationalism in the borderarea is relevant topic of discussion considering the fact that the state borders established by post-colonialism not only split different ethnicities, but also same ethnicity because of different nationalities history within the same ethnicities (Tirtosudarmo 2005; Aragon 2012; Aspinall 2007; Barker 2008). The state borders do not always follow the dividing line between areas of culture, language, tribe, nation, or different economic units (cf. Ulaen Lapian 2009, 2012, p.61). This is in contrast to nationalism in Europe which initiated the establishment of some nation states with clear territorial boundaries. Colonialism process has been central in spreading the concept of the nation state like this. Starting from the reality in Europe, Wadley views (2002) that state boundary is a line which separates the different social systems and the border areas become marginal areas whose legitimacy depend on the policies of the central government. This perspective assumes a proposition that might be mistaken which states that the level of nationalism in the border areas is lower than in the center.

Nationalism in this study is viewed as part of sociological perspective which refers to the attachment to national in-groups which love and are proud of their Homeland; and perceptions that the country is superior as compared to other countries (Coenders 2001; Béland and Lecours 2005). This view is rooted in the concept of Adorno (1950, p.107) who thinks that nationalism can be divided into patriotism and pseudopatriotism. According to him, nationalism is: "Certain blind attachment to national cultural values, uncritical conformity with the prevailing group, and the rejection of other nations as out-groups" (Ibid.). Many 
contemporary nationalism studies in sociological perspective in Europe have been done, for example Kleinpenning and Hagendoorn (1993), Todosijevik (1998), Coenders (2001) and Lactheva (2010). They generally use nationalism to observe the phenomenon of romantic nationalism and chauvinism in European countries. In contrast to these previous studies, this current study will only see nationalism in Indonesia in the perspective of romantic nationalism, which is owned by the residents in the maritime border (Mietzner 2006; Trajano 2010).

The concept of nationalism in this study is theoretically defined as knowledge, feelings, and social practices of loving the Homeland including the cognitive, affective, and behavior aspects. The cognitive aspect is the knowledge of Indonesia as a country that has geographical and political boundaries. The affective aspect is the sense of being citizens of Indonesia. And behavior aspect deals with practices instilling a sense of nationalism in everyday life (Elson 2010).

The study of nationalism in the border areas that have been done before (Noor 2013) merely focused on the evaluation and maintenance of nationalism that is done by the state. According to the study, the existence of state sovereignty is examined in the context of how far the country is able to realize and maintain a sense of nationalism within its own people. This study assumes that the greater independence in the management of nationalism, the sovereignty of a country will be more increasing. As a study from Noor, this paper also tries to describe on how far nationalism is managed by state institutions in the context of safeguarding national sovereignty. However, in contrast to that study, this paper emphasizes how far the border residents know, understand, feel and interpret the sense of nationalism in their everyday life. Another aspect that we want to search in this study is how the sense of nationalism is understood by the state and embodied in rituals and how the extent of the country's nationalism finds its meaning in the context of border communities.

This study also assumes that nationalism which is defined by the state can be seen through the knowledge, feelings, and practices of nationalism maintenance. However, the understanding and social practices carried out by border residents are often different from the nationalism spirit which is constructed by the state. Therefore, there is still a gap between the alleged national insight to the meaning of nationalism which is represented by social practices in the daily life of border area residents. Referring to the writings of Ben Anderson (1991), nationalism is defined as an imagined political community. Often, nationalism has failed to find relevance and is misunderstood by the people when they are presented in the context of economic, political, and social culture. The concept of nationalism as an attempt to maintain a sense of nationalism is not sufficient to instill nationalism; it needs more than that, especially dealing with justice, welfare and prosperity.

\section{Knowledge about Indonesia and Sea Border}

The knowledge about Indonesia includes knowledge that Indonesia is a nation state with its territorial boundaries. Referring to previous studies (Noor 2013), that the four pillars of nationality consists of Pancasila, the 1945 Constitution, the Republic of Indonesia and Unity in Diversity which can be regarded as the paradigm of the concept of nationalism. Therefore, public knowledge about the four pillars is included in the category of knowledge about Indonesia as a nation state.

In connection with current knowledge about Indonesia, almost all of the informants in Sangihe mention that Indonesia is envisioned as an archipelago of thousands of islands from Sabang to Merauke, rich in natural resources and human resources, and occupied by various tribes and religions. This view is obtained through socialization conducted by school institution primarily concerned with insight of Indonesia through Pancasila and Civic Education and Social Sciences (IPS). ${ }^{.}$The imagination of most informants about Indonesia as a count-

\footnotetext{
1 The interview of Cahyo Pamungkas with KFY, a
} student of University of Riau, 3 April 2014 in TBK. 
ry which is rich in natural resources is based on the reality in Sangihe as a region which produces fish and copra has supported this argument (Kreuzer 2006; Menchik 2014).

The knowledge of Indonesia is not new for people living in the border. The observation at Sangihe in May 2014 showed that students of fifth graders have gained the knowledge of Pancasila, the 1945 Constitution, the Republic of Indonesia, Pancasila eagle emblem, flag, and Indonesia Raya Anthem. They are able to distinguish between Jakarta and Manila. Sangihe people have a preference over the Philippine radio to hear because most of them can speak Visayas and Indonesian radio cannot reach them. Mastery of knowledge about Indonesia, according to one informant, has increased compared to the 1960 s where the residents in the border were more aware of neighboring countries and even traded with the Philippines pesos. According to him, the ignorance of Indonesia at that time was due to lack of access to information and communication technologies, so that they knew more about the Philippines that was located closer and reachable by sea transportation. ${ }^{2}$

The field finding in Marore Island, Sangihe shows that the knowledge and the feeling of owning Indonesia have been imparted to students since they are in primary school, including the belief that the Homeland is a nonnegotiable price. However, it does not mean that people Sangihe always choose products from Indonesia because of the price of the goods from the Philippines are cheaper with more attractive packaging, such as: canned food and beverage. 3 They argue that, for example, the production of the Philippines sweeter drinks and canned food taste better, whereas canned food from Indonesia are often easily damaged because of the long distance during shipping. In this

2 In 1945 and 1946, Sangir and Mindanao people who traveled from Sangihe to Mindanao had not understood that they entered the different country areas. Just in 1956, Indoneisan and Philippines governments managed the sea traffic for traditional shipping through Border Crossing Agreement (Aswatini 1995, p.36).

3 Interview of Cahyo Pamungkas with Mauntung, teacher of SD Marore, 24 Mey 2014 in Marore. context, the knowledge and confidence that Homeland is nonnegotiable price is not directly related to the choice in consumption behavior.

The mastery of the knowledge about Indonesia cannot be separated the sea border. Based on the interviews with a number of informants, particularly from traditional fishermen, they know that Indonesia, Malaysia, and the Philippines are geographically bounded by oceans. However, because their boat is not equipped with a Global Positioning Satellite (GPS), they do not know exactly where the international boundary line is. A fisherman from Tanjung Balai Karimun in the interview only indicated if the boat meets with a group of tanker vessels, then it can be concluded that these water is outside Indonesia. The same response was delivered by the Head of Bappeda Sangihe that for all this time, the local government does not know the clear coordinate between Indonesia and the Philippines, there are only imaginary border but it remains unclear (Head of Bappeda, FGD Tahuna 2014).

The public ignorance in Sangihe on this international sea border encourages illegal activities. The terminology of illegal itself comes from the perspective of modern foreign country in the perspective of local border communities. Referring to Tagliacozzo (2005), people in Sangir, before the 19th century, did not recognize the concept of international maritime boundaries. Before the establishment of the colonial state, people in both areas freely conducted shipping activities from their territory to the islands in the Philippines. The colonial government then controlled the border during the post colonial period. Although Indonesia and the Philippines have been separated politically, residents in these three countries still run the international shipping activities which have been carried by their ancestors both legally and illegally. Knowledge of the modern state and the post-colonial nationalism seems less to find relevance. In other words, there has been a gap in knowledge about Indonesia as a modern country and practices are illegal to cross an international border. 
From a number of interviews, people in the order area are not only aware of Indonesia as a nation, but also illegal activities which occurred in the international sea. Some of the informants in Karimun convey various smuggling activities through the international maritime boundary line (Swastiwi 2011, p.67).

Reflecting on a variety of illegal activities that have occurred in international water territory, the main problems that arise are not because of the Indonesian political ignorance, the international boundary line, or a low level of understanding of the national vision. The phenomena happen because of the lack fulfillment of people's basic need by the government.

In the case of sea border in Sangihe, some informants, especially from the bureaucracy and activists of non-governmental organizations, suggest that traditional trade traffic in the waters of Pulau Marore and Miangas after the Treaty of 1974 is limited to agricultural products with a maximum price of 250 USD. Filipinos who will go to the Marore Island, Indonesia or Marore people who will visit Balut Island, the Philippines, are obliged to use cross-border pass. ${ }^{4}$ But in practice, especially after the 1998 reform, most Filipinos enter Indonesian water without going through the islands which are stipulated in the 1974 agreement such as Marore, Miangas, Balut and Sarangani islands. In fact, after 2002, the fishing boats from the Philippines with Filipinos which is also one of the tribes in Indonesia are referred to as SAPI (Sangir-Philippines) or PISANG (Philippines-Sangir), Sangir to enter Indonesian waters illegally. Indonesian fishermen themselves tend to sell fish to the Filipino fishermen who enter Indonesian water illegally rather than selling them to the city of Bitung because the distance to the city of Bitung is further and it has lower fish prices. Illegal fishing is the key issue in Sangihe; there is violation of the territorial sea that has not been declared significantly as a violation by government. ${ }^{5}$

\footnotetext{
4 Interview of Cahyo Pamungkas with Rudi Mokoginta, Manado, 19 May 2014. 5 Interview of Cahyo Pamungkas with Letkol
}

In addition to fishing, as happened in Karimun, fuel, gamecock, weapons, and liquor are also smuggled through international sea. Fuel smuggling from Indonesia to the Philippines exists because of the price gap in the two countries; smugglers from Indonesia bought it for 6,500 IDR per liter and sell it to people in The Philippines for 15,00o IDR per liter. Gamecock is sold to Manado because some people have a habit of doing cockfights. The smuggling of weapons is allegedly done through Marore and Miangas Islands but they have not been caught because most cases of smuggling is done through the remote islands that are uninhabited (RM). ${ }^{6}$ And liquor is generally smuggled through the Port Tinakareng, Tahuna Island.

The knowledge of the sea border which is more adequate is held by security officials. Field research also has found that as a form of nationalism, officials from the Navy, Marine Police, and Customs conduct patrols in maintaining maritime sovereignty of Indonesia.

The notion about illegal activities, of course, is not directly associated with the ownership of nationalism. However, if it is viewed within the framework of the national ideology, these phenomena can be placed within the framework of nationalism maintenance. The existence of many illegal activities in the territorial waters of Indonesia as presented by informants exhibits the individual perpetrators of illegal activities and elements of maritime security guards who may have deep enough knowledge about Indonesia, but are obviously lacked of insight and meaning on nationalism. For the perpetrators who guard the waters, letting and allowing illegal activity can be interpreted as a declining sense of nationalism because they do not maintain state sovereignty in the waters. However, this argument does not pinpoint if it is imposed to the perpetrators of the illegal activity from

Saud, vice commander Lantamal Manado 19 May 2014 in Manado.

6 Interview of Cahyo Pamungkas with Rudi Mokoginta, Head of BPPD North Sulawesi 19 May 2014 in Manado 
the grass-roots level. They perform this action because the state has not fully asserted sovereignty in the economic field to improve the welfare so they are forced to commit an illegal act. In this case, if we use the analysis of Marx (1844), the nationalism is placed in the base material infrastructure as a basis for enforcement.

\section{Pride as being Part of Indonesia}

One aspect of nationalism is the pride for their national identity. This section outlines on how far people living in border have a sense of pride as a nation of Indonesia which is understood, in terms of Huntington, as "imagined political community". National pride of residents in the border area appears as a logical consequence of the success of countries in carrying out national development in meeting the needs of society, especially transportation and communication (Nainggolan 2004, p. 13). Lack of compliance will result in reduced welfare and national pride, and in the future could threaten national integration.

One of custom leaders of Sangir in Tahuna, Oka Makagangsa, said that the political sovereignty of Indonesia can be seen in Sangihe. Sangir indigenous people feel proud to be part of the Homeland, and obey the rule of law in Indonesia. Therefore, verbally, the loyalty of indigenous people in the border toward the Homeland must not be doubted although there are still many economic problems encountered by the Sangir in general. ${ }^{7}$

The reality is found in Marore Island, Sangihe. GMIT Marore Head of the Church, in the FGD mentioned that nationalism in Sangir will never fade because they sell fish on the Filipino traders. ${ }^{8}$ In contrast to the Talaud people in Miangas Island who raise the flag of the Philippines, Sangir people do not have a political orientation to the

7 Sangir people in this study are the people living in Sangihe archippelago and speaking Sangir Language which consists of severeal dialects such as Kendahe, Tahuna, Manganitu, Tamako, Tabukan, Siau, and Tagulandang (Parengkuan 1984 cf. Zaelany \& Agustina 1995, p.22).

8 FGD in Tahuna 2014.
Philippines. The trust of Sangir people to the Homeland is forever instilled over generations. As the efforts to increase nationalism because of the limited number of fish traders from Indonesia, he works in the business of trading fish and selling fish purchased from Sangir People in Marore to the Philippines. According to the statement, the business grew from selling 1 ton of fish per week to three tons of fish per week. But they fleet only to Batuganding in Balut Island and were not allowed to enter Philippine waters because it does not have shipping documents. From the fishing business, he felt proud that as part of Indonesia, he has contributed in improving the welfare of the majority of Sangir people.

Colonialism intervention in the formation of the border was also conducted in the Sangihe-Talaud. Munster agreement in 1648 between the Netherlands and Spain makes the Sulawesi Sea become colonial boundaries. The area of the north belonged to Spain, with Manila as the center, and the area of the south belonged to the Dutch, with Ternate as the center (cf. 2003 Lapian Ulaen et al. 2003, p.46-47). Since that time, the status of Sangihe and Talaud Islands region switched from commercial trajectory into landstreek van Menado. ${ }^{9}$ Sangir people must obtain a travel permit from the Dutch controlleur in Tahuna to go to the Philippines. Those who sail without permission will be considered to be a pirate. In 1898 , the Government of the Netherlands and the United States signed the Treaty of Paris that determines the boundary between the Dutch East Indies with the United States in the Sulawesi Sea. Delimitation of the state border is the colonial legacy that separates the cultural community.

\section{Rituals of Nationalism}

Sense of nationalism is not something that is

9 Study from Hayase et al. (1999) and Lapian (2009) show that the Kings in Kendahe, Sangihe dan Mangindano Islands, The Philippines are still from the same decendant. Mangindano Kingdom regards Kendahe as part of its teritory, also, Sultan Buayan regards Tabukan Kingdom in Sangihe as part of its teritory. 
taken for granted or graced from the top, but it is something that is socially and politically constructed by state institutions through social processes, namely the maintenance of nationalism. Nationalism is instilled by ideological state officers who can be called with the rituals of nationalism. The rites in traditional societies, referring to Durkheim (1967), aims to promote solidarity and social integration done through the creation of specific symbols. As a rite in traditional societies, nationalism maintenance efforts are made and institutionalized repeatedly.

Most interviews indicate that there are systematic efforts of the institutions mentioned above to teach the four pillars of nationalism, namely Pancasila, the 1945 Constitution, the Republic of Indonesia, and Bhinneka Tunggal Ika. Educational institutions from elementary to high schools in Gramsci's perspective can be regarded as an instrument of the state to instill ideology toward civilians. On the other hand, these practices sociologically can be seen as rites of nationalism, which is often defined theoretically as ceremonies by using symbols that are held for the purpose in fulfilling the group solidarity and at the same time, maintaining social integration. The implications of such nationalism rites are public knowledge about the teaching of Indonesia which is understood within political conception on the Homeland and its symbols.

Based on the interviews with most of the informants, the maintenance of nationalism in the border areas of Sangihe is done through basic education institutions such as Civic Education which has been taught to students from fourth grade elementary school. During the New Order, the materials on these subjects were taught through Pancasila Moral Education (PMP) and the Education of National Struggle History (PSPB).

The tradition of nationalism socialization through schools and churches is done in Sangihe. ${ }^{10}$ According to one elementary

10 Portuguese Missionaries came the first time spreading Catholicsm in 1563 in Siau, Sangihe Island. Then, Dutch missionaries taught christianity since the end of 17 th century. Since that school teacher in Marore, Mauntung, nationalism and citizenship education program starts from elementary to high schools to require students to perform flag ceremony, students who do not participate or come too late will be given quite penalties such as saluting the flag and corporal punishment. They must be aware of this and respect national heroes through flag ceremony. The spirit and soul of nationalism are instilled in the students so that they appreciate the Homeland, have passion in protecting NKRI, and to be proud of it. Schools and churches are examples of two institutions that instill nationalism in Marore island. Through churches, for example, the Sunday sermon is often filled and inserted the talk on sovereignty of the Republic of Indonesia. Through ceremonies and civic education, students are taught to have a sense of nationalism. Approaching the state speech August 16, students are assigned to hear the president's speech, make notes, discuss with parents and make a summary.

Another attempt to increase the sense of nationalism of people living in the border area is through ceremonial events, especially the anniversary of independence of Indonesia every August $17^{\text {th }}$ either by means of official ceremonies and carnival which are held in each village and sub-district in the border area. The celebration of Independence Day is organized by Sangir people living in Sangihe. The memorial service is held on a large scale in the District Marore involving students, government officials, and citizens. These elements of people are trained by the Army of the Village Kabiyo, Matotuan, and Marore for one month. Camat (the head of district) and Koramil (District Military Commander) play central role in the celebrations. Commander of the ceremony is from Koramil and the head of ceremony is Camat. According to Camat Marore, he always tells: "Do not forget that we are citizens of Indonesia. Although we have many brothers of the blood in the Philippines, Jakarta is far from in the eye but close to our heart,

era, the church provided medical services and basic education to Sangir people besides religious service (Brilman 2000, p.123). 
Manila is close in the eye and far from our heart." Camat Marore also urges every citizen to have sense of patriotism and pride as a citizen of Indonesia. The Marore phenomenon which occurs since the time of the reform is that how hard for the people to raise the red and white flag, but they prefer to raise the flag of the World Cup participating countries.

Government in the border area also plays the role in maintaining nationalism of citizens, although it is still formal, elitist, and artificial. The story about instilling patriotism in Sangihe is delivered by the Head of Kesbangpol, HE Lalinda, who tells about the needs to love Indonesia. The seminar on nationalism and allegiance to Indonesia is conducted by Bakesbang with the content of history of struggle establishing the Homeland and how to love the Homeland. " The participants were citizens of Marore Island and Miangas as the outer islands. Seminar was conducted by inviting community and religious leaders, held regularly once a year in the name of national awareness seminars. Speakers in the seminar come from Kesbangpol Agency, Regency of Sangihe, Navy, and Army.

Rather different thing is also conducted by the Navy in Sangihe which develops assisted village for the defense function in Miangas and Marore Islands, where the two islands are spearheading the development of nationalism of citizens of border communities in everyday life. ${ }^{12}$ Mechanisms in fostering national awareness of fishermen are set in the development program of national maritime power potential. Fishermen are indoctrinated by the Navy not to violate the international maritime boundary line (over 12 miles) and to report any violation of the territorial sea by foreign parties. Another form of guidance is by asking fishermen to catch fish when the group establishes cooperation. Counseling and approach to

11 Interview of Cahyo Pamungkas with HE Lalinda, Head of Organitational Division Kesbangpol Sangihe 26 May 2014 in Tahuna.

12 Interview of Cahyo Pamungkas with vice commander of TNI AL Manado 19 May 2014 in Manado. coastal communities are held by the Navy because they are the eyes and ears to safeguard the state sovereignty. Guided village defined by TNI-AL is a coastal community that is difficult to reach by sea transport, close to the international boundary line, and easily influenced by strangers.

To instill a sense of nationalism, the NKRI expedition which is by raising the red and white flag in the underwater of Marore was organized by the Ministry of Home Affairs and Dephankam in 2013. This event is referred to as a declaration of proclamation in Marore that NKRI also includes the water area of Marore. Such events s involve a lot of security personnel and officials of the Central Government and less useful for Sangir people.

\section{Challenges}

The important question now is how far the maintenance of nationalism in the border area is still relevant and needed by the community. Maintenance of nationalism is put in the context of welfare states in which sovereignty of country depends on the efforts to comply with the welfare of society (Nurdin, 2011, pp. 21). Almost all informants in Sangihe answer that sense of nationalism is still needed and should be enhanced by the citizens at the border.

To instill a sense of nationalism, the central government has established a border monument on the island Marore indicating that this island is the outer islands of Indonesia and belongs to the Homeland. The needed nationalism is nationalism which accommodates cultural fusion between the Philippines and Indonesia. The tendency today shows there are massive efforts of the Government of Indonesia to maintain sense nationalism in the middle of border communities. The observations also show that there are many Sangir people who have been settled down in the Philippines and come back to Indonesia then stayed in Marore Island and surrounding islands during the six months prior to the distribution of direct cash assistance. They are proposed by their family in Indonesia to be incorporated into the pre-prosperous family. This is so- 
mething that is not owned by the Sangir in the Philippines. According to the rules applicable in Sangihe, the Sangir or from other tribes who have lived on the island entitled to be registered as a citizen of the village and obtain their rights as citizens of other villages.

The maintenance of nationalism is often faced with the constraints that come from the security forces and the Government's inability to perform its functions. Several informants in this study say that sometimes, the violence occurs between society and the authorities with border security officers, thus eliminating the meaning of nationalism in the midst of society. One informant told us that in 2012 there had been a fight between individual soldiers with the community. ${ }^{13}$ One individual soldiers destroyed several fishing boats on the island of Sangir people in Marore after these people were involved in a brawl with the residents. Another story is told by Head Marore about the conflict between the elements of the Army and Navy in 2012. The main problem is the non-involvement of the army in the supervision of cross-border post by Cross Border Agreement of 1974. The trigger of this conflict is the dancing party which resulted in a fight between rogue Army and Navy.

This kind of misbehavior of the security force undermines citizens' awareness of the need for the Homeland. Ironically, they are the symbols of the country and they damage it. The informant said: "We do not want any troops sending if their behavior hurts the feeling of community. Their presence in here is because the commander's orders and not from the needs of society in Marore. "There is a kind of jealousy towards the existence soldiers in Sangir who represent the Homeland with weapons and receive a regular salary. Meanwhile, in view of the Sangir, soldiers merely eat and exercise without working hard.

Another issue is the high level of economic dependence on the Sangir Marore toward the Philippines. According to the

13 Interview of Cahyo Pamungkas with Mauntung, teacher SD Marore 24 May 2014 in Marore.
Deputy Commander of the naval base of Manado, the nationalism of Sangir people at the border is still pretty good; the question that often arises is the outer islands (Marore, Mattutuang, etc.) economic life is still very dependent on the General Santos. Goods of basic needs on the islands will be fulfilled from Manado by sea, but residents in the islands buy the goods from The Philippines because it is cheaper and closer. This issue is caused by the Government of Indonesia has not been able to generalize the price level between regions due to the high cost and lack of transportation problems. Cruise from Tahuna to the island by ship pilot Marore is done once every two weeks by four pioneering vessel for 19 hours from Tahuna to Marore. By contrast, in Malaysia and the Philippines, the price level is relatively more evenly across regions with maritime transport better.

Almost all informants in Sangihe have the same view that the main problem the maintenance of nationalism in the border areas is the welfare of the people that live in the outer islands. One journalist from Tahuna tells that political sovereignty in the border area becomes worthless when its natural resources are looted and the welfare is ignored. According to him, the main problem of political sovereignty in the border enforcement is not a security approach; it is prosperity of people. ${ }^{14}$ The attention of the Central Government toward the border area is generally very low, indicated by low DAU and decentralized funds. Treatment of Central Government in funding the construction of the border is inversely to meet the needs of border communities.

Poverty is a portrait of the lives of some Sangir people. Most residents work as farmers and traditional fishermen who are generally subsistence. Food and non food needs must be purchased from the outside island with a very high price (Aswtini et al. 1994, p.9). Most Sangir children drop out of school because they do not have the financial security in continuing their higher education, so they are unemployed or wor-

14 Interview of Cahyo Pamungkas with Maiko, NGO, 25 May 2014 in Tahuna 
king as a fisherman to help parents or as construction laborers in infrastructure development projects. From a small age, the children of Sangir people have been taught to live independently as archery taught how to fish and trained to catch the sharks by parents or siblings. This depicts a portrait of poverty Sangir people who in the future has the potential to reduce the feeling of nationalism in the border area.

Many local governments have attempted to improve the economy of the Sangir. Camat said that during this time there was a policy to tolerate Indonesian fishermen who want to sell the fish below 1 ton from being granted by the customs tax in Batuganding Philippines, Sarangani. Based on Cross Border Agreement in 1974, crossborder activities in Marore must be only for cultural, family and religious visit but given the ease of making the transaction fish from Indonesia to the Philippines can take place through the border crossing Marore to avoid fish smuggling. The regional government building Marore fish market on the island, but has not been used by the Sangir. Sales of fish on the island Marore usually occurs through barter in Marore port where the fish buyers from the Philippines paid with commodities such as fishing equipment, paint, beverages, agricultural tools. Buyers of fish from the Philippines also redeem items of daily life from the Philippines with fish, cigarettes, or soap from Indonesia.

Discussing the Homeland often shows the unfit picture between the reality and the ideals as set forth in the preamble of the 1945 Constitution example the tradition of patron-client politics that are often detrimental to public interest. For example, principals who often criticize Regents policy because it is not in accordance with the aspirations of the people are easily dismissed from their post. The salaries of teachers who teach in remote areas have not been paid in full, while receiving allowance is difficult to obtain because most teaching hours of teachers in Marore cannot exceed 24 hours a week for a single field of study. Most teachers in the border area concurrently take charge as religious organizations and employer because they have extensive knowledge, master Indonesian language, and has closeness with the community. Ironically, as a teacher at the school who doubles as the caretaker of the church, they feel less valued and appreciated by the Department of Education, but this task is part of the Homeland enforcement efforts through the development of religion. Churches and schools are institutions at the border who have contributed in supporting the unity of the nation.

Another obstacle emerged in the maintenance of nationalism in Sangihe is that there are a lot of Filipino Sangir settled in Sangihe and in Sarangani, Philippines. According to the Head of institutional relations, Kesbangpol Agency Sangihe, HE Lalinda, Sangir people who live in the Philippines amounted to 6o thousand people who possess fraternal relations with their counterpart in Indonesia. In the 1970s, people Sangir Miangas and Marore Islands were more familiar with the President Marcos than President Soeharto for television broadcasting Philippines has been around since long time ago. Filipino TV broadcast can be captured directly by the people at the border. Indonesian TV Channels just entered Miangas and Marore in 1980 after TVRI transmitter was built, and in 1990, the Indonesian television can be captured and enjoyed by people on the border.

At present, most fishermen in Sangihe are the Sangir Philippines where they are regarded as second-class citizens in the Philippines. Their arrival to Sangihe is just earning a living, working as a fisherman. Most employers here like employ them as fishermen because they are professionals that are able to stay at sea for many days to catch fish. After the employment contract is finished, they return to the Philippines. However, they are not given an identity card, although the card has a temporary residence permit (Permit) for two weeks up to one month.

Filipino fishermen or the SAPI / BANANA are formally coming through the entrance gate of Marore or Nusa Tabukan guarded by Posad. If the attention of central government to the border area is lacking, the value of the Philippines will increase, for 
example, public facilities in the Philippines is much better, then Sangir people will be more easily influenced to join the Philippines. Based on the rationale to raise national consciousness and a sense of nationalism for border community, the infrastructures were built such as passenger port, ferry ports, proposals, Posad, Immigration, and roads. According to the Head of National Unity, in the present situation, SAPI fishermen are taking our fish. Although there is Navy post in Marore, they can get in when there is change of troops. The average Filipino fishermen stayed for 3 months before they return to the Philippines.

The debate on the nationality of the Sangir Philippines has not shown any common ground between the Government of the Philippines and Indonesia. They are said as the Philippines but ethnically, they are one of the Sangir tribes, Indonesia. Likewise, when people say Sangir, Indonesia, they do not have a clear identity because mostly they stay in the Philippines. The livelihood of the Filipino Sangir is mostly as traditional fishermen or farmers. There is an effort to clarify the status of Indonesian nationality but it is hampered by Law No. 32 of 2008 which requires the provision of ID cards which should be based on the family card. They have been asked to make a domicile certificate from the Indonesian consulate general in Davao as a first step to make the Indonesian ID card.

\section{The Meaning of Nationalism Within Social Perspective}

As what have been described in the previous section of this paper, nationalism that is discussed is the meaning defined by the state. For example, that nationalism is identical with the knowledge and love of the Homeland. The duty of the ideological state officers to promote nationalism is conducted through the mobilization of citizen participation where the understanding of such nationality meaning is only superficial. The government's inability to deal with problems in border areas such as education and basic health, transportation, availability of fuel makes the discourse of nationalism to be questioned. The next question is how the public at the border understand, interpret, and describe the concept of Indonesian nationalism in their everyday life. Almost all informants from civil society have expressed the view that ordinary people, mostly educated middle to bottom, interpret the essence of nationalism as welfare-related aspects, such as the availability of jobs and insufficient daily living needs. Moreover, the nature of nationalism also deals with the availability of access to education and health for people living in remote islands. The gap analysis in this section shows that nationalism which is politically understood will find its meaning if it is implemented in social and economic life.

Although there are still obstacles in socio-economic development of border areas, the majority of informants agreed that national values and national identity should remain implanted to the public. Nationalism can be interpreted as a harmonious and tolerant life based on national values stretcher. One informant from the Government of Karimun, Rosmansyah, said that there should be an effort to promote nationalism widely, increasing inter-ethnic cooperation, and resolve inter-ethnic tensions. The level of inter-ethnic and religious tolerance in Karimun is still high despite the majority of the population $(80 \%)$ are Malay Muslims. National Unity Forum (FPK) has been established as a tool to improve intergroup ethnic assimilation to maintain harmony. However, the socialization of national identity will not be effective if economic affair has not been completed. When basic needs are met, then people will think of and fight their identity. The level of public participation in major ceremonies such as the carnival is not about the participation size but more as the result of mobilization. Pancasila education needs to be held back to inculcate national values and build character, manners or national identity.

According to interviews with several informants, it is indicated that the maintenance of nationalism and increasing understanding of the national vision must be followed by efforts to achieve people's prosperity. 
Border regions are generally areas lagging behind in development and prosperity and are still far from expectations. Therefore, nationalism becomes less meaningful when the gap between the ideals of freedom with reality is still quite large.

To instill nationalism, government is suggested to focus more on the improvement of people's welfare. In other words, the government should give attention so that community's economical needs are met. The essence of nationalism is welfare for the poor. Keeping a sense of nationalism can be done by improving welfare. Therefore, the concept of nationalism does not merely ring in public, perhaps for those who are educated will understand this concept, but for those who have not been prosperous this concept is questionable.

Talking about Indonesian nationalism for some Sangir people will result in disappointment because their condition under Indonesia is relatively less autonomous than when they were under the State of East Indonesia (NIT). The romanticism during RIS begins to reappear due to lack of attention to the welfare of Sangir people after they joined the Homeland. Head of Bappeda in Sangir argued in FGD that Sangir had relatively more autonomy both political and economical sovereignty when they become one of the 13 Autonomous Regions under NIT in 1950. Between 1950 and 1970, the relationship between the Sangir and the Philippines was set in Border cross Agreement 1956 which regulates the cross-border trade between Sangir and Sarangani. As a result, the exports and imports between the Sangir and the Philippines were increased and relatively more prosperous. This is often said that Sangir people enjoyed such prosperity in 196o because of free trade between Indonesia and the Philippines in this area. However, after the New Order regime which then set the Sangihe area as an area closed to trade, the welfare of the people Sangir was declining. The cross-border agreement only regulates the traffic culture and religion, but not free trade. This is the one that drives the smuggling happens in the area as described in the previous section. Commercial trade lane between Indonesia and the Philippines (non-traditional) can only be done through Manado, whereas Marore Island is only for traditional trade flows whose value is below 250 USD.

\section{Identity Dualism of the Philippino San- gir People}

The Indonesian nationalism is formed by the diverse border communities. Several interviews reveal the fact that one of the characteristics of the sea border is the level of plurality tribes which is quite high. Anthropological nature of the beach is often seen as more open to experience assimilation by immigrants compared to residents who live in rural areas (Sam 2007, p.105). The relationship between the tribes in this context is viewed in conjunction with efforts to maintain national awareness manifested in living peacefully and side by side. The process of identity formation of the Malays or Sangir is done without reducing the attachment to national identity of Indonesia. The maintenance of nationalism can be done to accommodate and provide space for the development of cultural identity of border communities in Indonesia (Suparlan 2002).

Cultural issue that may affect nationalism is the presence of Sangir Philippines or Filipinos Sangir who settled in the outer islands of Indonesia and the Philippines. There is no accurate data on the number of people Sangir in the Philippines. The interview with the Chairman of the North Sulawesi BPPD shows that the majority (90\%) of the population in the southern Philippines Balut Tribe is a Sangir tribe. ${ }^{15}$ Overall, the number of residents in the southern Philippines SAPI is around 30,00o people, but the registered people at the Indonesian Consul General Davao are only 5,200 residents. They neither have a passport nor ID card. When they are asked by the Consul General in Davao, they only give information of family name and the name of the island they came from. The Philippines recognizes the existence of citizens who live in the southern Philippines as undocumented ci-

15 Interview with Rudi Mokoginta, Head of BPPD North Sulawesi, 19 May 2014 in Manado. 
tizens, resulting to the unavailability to access in formal sector employment and land ownership. Nevertheless, they still have a high sense of nationalism and regionalism to Sangihe, proven by their expectation to return to Indonesia (Widayatun et al. 1997, p.52).

Almost all interviews in Tahuna and Marore said that people of Sangir living on the island of Matutuang, Kawio, Kawaluso, and Marore have relatives or siblings with the Sangir Philippines living in the southern Philippines namely: Balut, Sarangani, General Santos, and Davao Islands. In fact, Matutuang population is mostly from people Sangir Philippines who had returned to Indonesia. They returned in the hope of a better life and clear citizenship in Indonesia. People who live in the island Mattuang until Marore prefer to listen to the Philippinesspeaking radio using Visayas language. This phenomenon shows how high the cultural ties between the sangir people with SangirPhilippines although it has been separated politically.

The phenomenon that threatens the sense of nationality of Sangir people in the future is the influx of people Sangir Filipinos who are working illegally as a fisherman on a boat fishing vessels in the waters of Sangihe. Based on the information from former members of the MNLF Sangir, a perspective that says there are political and territorial borders between Indonesia and the Philippines is the perspective from Jakarta. According to them, there is no boundary separating the Southern Philippines and Sangihe since hundreds of centuries ago. Even if in Marore and Batugandhing the Sarangani border crossing is built, but the number of illegal border crossers between the two countries in the hundreds and even thousands through a direct path from Tahuna (Map and Tinakareng) to Sarangani. For them, this path is called the path of the ancestors which is free and open sea trajectory since the post-reform. Formerly, in the New Order since 1970, every illegal boat crossing from the Philippines to Indonesia, if they met with naval patrol, they would be immediately shot so smuggling activities could be restricted and suppressed to the maximum by using military force. Since the fall of the New Order regime in 1998, the line ancestors is reactivated and illegal border crossers are not scared anymore to go across these paths to carry the fish.

These illegal fishermen use Philippines boats and pam Fuso with Indonesianflagged fishing using permit letter from the Government of Indonesia. They are anchored in the harbors of Peta and Tahuna. In 2011, they just stay on the boat, but now they've dared to go ashore and transact openly. They are suspected of carrying and selling drugs and narcotics, short-barreled firearm, in addition to selling fish. Every law enforcement officers came to the beach, approach it and resolve it peacefully. In fact, when the Philippine boat pam was caught in Indonesian waters, they allegedly bribed the security forces and prepare the weapon. Based on a number of interviews with officials of inspection DKP, head of Bappeda, expert staff regent, and ABK Philippines obtained information that the boats pam boat Philippines-flagged Indonesia is legal when it is seen from the documents cruise, but the crew could not show their credentials whether they are citizens of the Philippines or Indonesia. Thus, the citizenship status of the Philippine fishing boat crew is stateless and illegally present in Indonesia. They only speak in the language Sangir and Visayas, a little English and Indonesian. The professionalism requirement for the knowledge and skills are met but the requirements of citizenship are not met at all.

\section{CONCLUSION}

Based on the explanation, it can be concluded that the level of knowledge in Indonesia as a modern country and sea borders, as well as an Indonesian national pride is increasing compared to the 1970 period due to the development of information technology and the cultivation of nationalism in the New Order. Nevertheless, there is still a gap between the knowledge of Indonesia as a modern country that has a certain territorial boundaries with social praxis that represents nationalism such as smuggling, illegal 
activities, etc. It is more because of the limitations of their economic life tha are still lagging behind compared to people living across the border.

The government has created some programs to instill the nationalism of border communities through. However, the findings of the field indicates that the nationalism is politically defined and constructed by the state, as measured by the understanding of the concept of nationalism, not sounding in reality, or can be less relevant to the socio-economic context of border communities. In other words, maintaining nationalism through the rites of the country has not been followed by the maintenance of border community welfare. The maintenance of a sense of nationalism can be done to accommodate and provide space for the development and cultural identity of border communities in Indonesia.

Martinez (1994) classifies the border region by its historical context into four types: alienated Borderland (no cross-border activity), coexistent Borderland, interdependent Borderland, and integrated Borderland. Referring to the view of Martinez, the relationship between Indonesia and the Philippines can be seen as interdependent Borderland, for example Indonesia provides abundant aquatic resources and the Philippines provides labor and fishing technology. In this interdependent relationship, nationalism in the border area is still politically strong, but their engagement in economic and cultural relation is equally strong.

\section{REFERENCES}

Adorno, T. W., Frenkel-B., E., Levinson, D. J., \& Sanford, R. N. (1950/1969). The authoritarian personality. W.W. Norton Company, New York.

Anderson, B., 1991. Imagined communities: Reflection on the origin and spread of nationalism. Verso, London.

Aragon, L.V., 2012. Copyrighting culture for the nation? Intangible property nationalism and the regional arts of Indonesia. International Journal of Cultural Property, 19(3), pp.269-312.

Aspinall, E., 2007. From Islamism to Nationalism in Aceh, Indonesia. Nations and Nationalism, 13(2), pp.245-263.

Aswatini, Bandiyono, S., Widayatun, Mujiyani, Setiawan, B., 1994. Mobilitas penduduk wilayah perbatasan indonesia-Filipina di Sulawesi
Utara. PPT LIPI, Jakarta.

Barker, J., 2008. Beyond Bandung: developmental nationalism and (multi) cultural nationalism in Indonesia. Third World Quarterly, 29(3), pp.521-540.

Brilman. 200o. Kabar baik di bibir Pasifik. Zending di Kepulauan Sangihe dan Talaud. Pustaka Sinar harapan, Jakarta.

Béland, D. and Lecours, A., 2005. Nationalism, public policy, and institutional development: social security in Belgium. Journal of Public Policy, 25(2), pp.265-285.

Coenders, M., 2001. Nationalistic attitudes and ethnic exclusionism in a comparative perspective: an empirical study toward the country and ethnic immigrants in 22 countries. Doctoral dissertation, Catholic University Nijmegen, 2001.

Durkheim, E., 1967. De la Division du Travail Social. Paris Les Presses universitaires de France.

Elson, R.E., 2010. Nationalism, Islam,'secularism'and the state in contemporary Indonesia. Australian Journal of International Affairs, 64(3), pp.328-343.

Hayase, S., Non, D. M., dan Ulaen, A. J., 1999. Silsilah/ tarsilas and historical narratives in Sarangani bay and Davao gulf regions, South Mindanao, Philippines, and Sangihe-Talaud Islands, North Sulawesi, Indonesia. Center for Southeast Asian Studies, Kyoto University, Kyoto.

Kleinpenning, G., \& Hagendoorn, L., 1993. Forms of racism and the cumulative dimension of ethnic attitudes. Social Psychology Quarterly. 56(1), pp.21-36.

Kreuzer, P., 2006. Violent civic nationalism versus civil ethnic nationalism: Contrasting Indonesia and Malay (si) a. National Identities, 8(1), pp.41-59.

Lapian, A.B., 2003. Pengantar. in A. J. Ulaen, Nusa Utara: Dari lintasan niaga ke daerah perbatasan. Pustaka Sinar Harapan, Jakarta.

Lapian, A.B., 2009. Orang laut, bajak laut, raja laut. Sejarah kawasan Laut Sulawesi abad XIX. Komunitas Bambu. EFEO, KITLV, ANRI, UGM, dan UNPAD, Jakarta.

Latcheva, R., 2010. Nationalism versus patriotism, or the floating border? National identification and ethnic exclusion in post-communist Bulgaria. Journal of Comparative Research in Anthropology and Sociology. 1(2), pp.187-216.

Martinez, O. J., 1994. Border people: Life and Society in the US-Mexico borderland. University of Arizona Press, Tucson.

Marx, K., 1844. On The Jewish Questions. Retrieve from www.marxist.org diakses pada 30 Juni 2008.

Menchik, J., 2014. Productive intolerance: godly nationalism in Indonesia. Comparative Studies in Society and History, 56(3), pp.591-621.

Mietzner, M., 2006. The politics of military reform in post-Suharto Indonesia: Elite conflict, nationalism, and institutional resistance. Policy Studies, (23), p.I.

Nainggolan, P.P.(eds.). 2004. Batas wilayah dan situasi 
perbatasan Indonesia: ancaman terhadap integritas teritorial. Tiga Putra Utama, Jakarta.

Noor, F., 2013. Negara dan kedaulatan politik, dalam M. Noveria (eds.), Kedaulatan negara di wilayah perbatasan: Tinjauan multidimensi (hal 97-138). PPK-LIPI, Jakarta.

Nurdin, M.F., 2011. Kedaulatan di wilayah perbatasan: perspektif kesejahteraan sosial. Puslitbang KPK LPPM Unpad, Bandung.

Parengkuan, F.E.W., 1984. Sejarah dan Kebudayaan Lima Suku Bangsa Asli di Sulawesi Utara. Fakultas Sastra, Universitas Sam Ratulangi, Manado.

Suparlan, P., 2002. Menuju Masyarakat Indonesia yang Multikultural. Jurnal Anthropologi Indonesia, 69 .

Swastiwi, et al., 2001. Sejarah Daerah Karimun. Dinas Pendidikan, Tanjung Balai Karimun.

Syam, N., 2007. Mahzab-Mahzab Anthropologi. LKIS, Yogyakarta

Tagliocozzo, E., 2005. Secret trades, porous borders : smuggling and states along a Southeast Asian frontier 1865 - 1915. Yale University Press, New Haven \& London.

Tirtosudarmo, R., 2005. Wilayah perbatasan dan tantangan Indonesia abad 21, in R. Tirtosudarmo $\mathcal{E}$ J. Habba (eds), Dari Entikong Sampai Nunukan. Pustaka Sinar Harapan, Jakarta.

Todosijevic, B., (1998, June). Relationships between authoritarianism and nationalist attitudes. (Paper presented at symposium: Authoritarianism and prejudices in an international and inter-generational perspective, CEU (Central European University), Budapest). Retrieved November 10, 2010 from http://www.personal.ceu.hu/students/98/Bojan_Todosijevic/ ENYEDI/OSIRIS1.pdf.

Trajano, J.C.I., 2010. Ethnic nationalism and separatism in West Papua, Indonesia. Journal of Peace, Conflict and Development, 16, pp.12-35.

Ulaen, A. J, Nugrahini, P., Setiawan, C., Dukalang, A., and Alinabur. 2004. Studi tentag sosial budaya masyarakat daerah perbataan: Studi kasus masyarakat Pulau Marore Kabupaten Sangihe. Balai Pelestarian Nilai Budaya Manado, Manado.

Wadley, R. L. 2002. Border Studies beyond Indonesia: A comprehensive perspective. Antropologi Indonesia. 26(67), pp.1-11.

Widayatun, Setiawan B., \& Bandiyono, S., 1997. Kondisi dan potensi daerah perbatasan IndonesiaFilipina di Sulawesi Utara. in Aswatini (eds.), Mobilitas penduduk dan pembangunan daerah perbatasan (pp. 39 - 88). PPT LIPI, Jakarta

Zaelany, A. A., \& Agustina. 1995. Mobilitas penduduk Kepulauan Sangihe-Talaud. in Aswatini (eds.), Migrasi kembali orang-orang Sangir Talaud dari Pulau-Pulau di Wilayah Filipina (pp.1740). PPT LIPI, Jakarta 